\title{
WŚRÓD ANIOLÓW I ŚWIĘTYCH EWOLUCJA FORM RZEŹBIARSKICH W PRACACH MARYLI LEDNICKIEJ-SZCZYTT
}

\author{
Magdalena KASA (Instytut Sztuki PAN, Warszawa)
}

Podczas wywiadu, przeprowadzonego w 1933 roku, rzeźbiarka Maryla Lednicka-Szczytt (1893-1947) wyznała:

To zaś, co najgłębiej odpowiada mojej potrzebie wewnętrznej — to tematy religijne. W pracy nad nimi znajduję ów nastrój oderwania się od rzeczy konkretnych, nastrój, który daje mi przeżycia najbardziej cenne ${ }^{1}$.

Ówcześnie Lednicka tworzyła przede wszystkim rzeźby portretowe, stąd też intrygujący wydaje się intymny wydźwięk tej wypowiedzi. Sugeruje on, że do dzieł o charakterze religijnym miała bardziej osobisty stosunek $\mathrm{i}$ - jak wykaże analiza formalna odmienną wizję kompozycji rzeźbiarskiej. Co znamienne, w żadnym ze znanych źródeł nie ma wzmianek, dotyczących deklaracji wyznaniowych artystki. Nie sygnalizował tego wątku w swoich Pamiętnikach również jej brat, Wacław Lednicki ${ }^{2}$. Badając rozwój twórczy rzeźbiarki, można spostrzec, że moment, w którym udzieliła wspomnianego wywiadu, stanowił cezurę zarówno w jej życiu osobistym, jak i zawodowym. Roz-

\footnotetext{
${ }^{1}$ I. Jabłowska, Artystka polska we Włoszech. Interview z p. Marja Szczytt-Lednicka, Kobieta współczesna $1933 \mathrm{nr}$ 33, s. 591.

${ }^{2}$ Por.: W. Lednicki, Pamiętniki, t. 1, Londyn 1963; tenże, Pamiętniki, t. 2, Londyn 1967.
} 
mowę przeprowadzono na chwilę przed zaplanowanym, dłuższym pobytem w Stanach Zjednoczonych. To właśnie tam, w późniejszym okresie, artystka zrealizowała pierwsze rzeźby na zamówienia kościelne.

W poniższym tekście rzeźbą religijną będę nazywać prace funkcjonujące poza oficjalnym obszarem kultu, choć wyrażające treści duchowe, podczas gdy przez rzeźbę sakralną rozumiem dzieła liturgiczne przeznaczone do konkretnych przestrzeni kościelnych $^{3}$. Artystka tworzyła prace o jednym i drugim charakterze, niestety obecnie znanych jest ich zaledwie kilka ${ }^{4}$.

W dorobku Lednickiej zagadnienia religijne pojawiły się już we wczesnych latach 20. Z powyższego cytatu można wywnioskować, że tego rodzaju dzieła najprawdopodobniej stanowiły pretekst dla osobistej ekspresji artystycznej, będąc przy tym nośnikiem najbliższych rzeźbiarce stylistyk formalnych. Technika ich modelowania różniła się od tej, jaką autorka posługiwała się w pracach na zamówienia prywatne oraz publiczne i z pewnością bardziej odpowiadała jej preferencjom, gdyż nie musiała spełniać niczyich oczekiwań. Co ciekawe, przy zestawieniu ze sobą rzeźb religijnych oraz powstałych w latach 40. realizacji o funkcji liturgicznej, widoczna jest zmiana w podejściu do rzeźby w ogóle.

Droga twórcza artystki zaczęła się od inspiracji kulturami pozaeuropejskimi i wiodła aż po wielką tradycję średniowiecznej sztuki sakralnej. Z pewnością na początkowe wybory natury rzeźbiarskiej w dużej mierze wpłynęła postać jej nauczyciela, Émile Antoine'a Bourdelle'a, u którego studiowała w Paryżu jeszcze przed I wojną światową. Mistrz zachęcał swoich uczniów do zainteresowania się nowym repertuarem tematycznym, w tym rzeźbą sakralną ${ }^{5}$. Wypada w tym miejscu przypomnieć, że powrót do pierwiastków duchowych $\mathrm{w}$ sztuce francuskiej stał się zauważalny na początku XX wieku i był jednym z elementów odnowy religijnej we Francji ${ }^{6}$. Poświadczyć to może spora ilość powstałych ówcześnie grup oraz stowarzyszeń artystycznych, mających na celu reformę sztuki katolickiej. Już w drugiej połowie wieku XIX istniało Société de Saint Jean, założone przez duchownego Henri-Dominique Lacordaire'a, a w pierwszych dwóch dziesięcioleciach XX wieku powstały kolejno Catholiques des beaux-arts (1909) L'Arche (1917), Les Artisans de l'Autel (1919) czy Les Ateliers d'art sacré (1919), którego pomysłodawcami byli malarze Georges Desvallières oraz Maurice Denis ${ }^{7}$. Innym ważnym francuskim artystą i teoretykiem sztuki, zainteresowanym odnową duchową i sztuką religijną, był kubista Albert Gleizes, którego myśl odbiła się szerokim echem w świecie artystycznym ${ }^{8}$. Inspiracje religijne obecne były również

\footnotetext{
${ }^{3}$ W. Bałus, Sztuka - idea - sacrum. Uwagi o XIX-wiecznych korzeniach wspótczesnej sytuacji sztuki sakralnej, Znak 1991 nr 12, s. 53.

${ }^{4}$ Zob.: H. Goodwin, The Harmonious Sculpture of Maryla Lednicka, The Polish Review 1946 nr 16, s. 8-10; I. Piotrowska, Maryla Lednicka. Great Polish Religious Sculptress (18951947), The Polish Review 1947 nr 11, s. 11; taż, Maryla Lednicka (1894-1947), Tygodnik Polski 1947 nr 14, s. 6-7; taż, The Art in Poland, New York 1947, s. 24-25.

${ }^{5}$ M. T. Diupero, Bourdelle w kręgu polskim, [w:] Paryż i artyści polscy 1900-1918. Wokót E.-A. Bourdelle'a, [kat. wystawy]. Muzeum Narodowe w Warszawie, 18 lutego-27 marca 1997. Koncepcja wystawy i katalog E. Grabska, Warszawa 1997, s. 33.

${ }^{6}$ C. Savart, Dwa wieki sporów wokót sztuki sakralnej, [w:] Historia chrześsijaństwa, red. A. Corbin, Kraków 2009, s. 334.

7 The Oxford Dictionary of Christian Art and Architecture, red. T. Devonshire Jones, L. Murray, P. Murray, Oxford 2013, s. 184.

${ }^{8}$ A. Gleizes, Posłannictwo twórcze czlowieka $w$ dziedzinie plastyki, Warszawa 1927; tenże, Art et religion. Art et science. Art et production, Chambéry 1970.
} 
w sztuce włoskich futurystów ${ }^{9}$. Warto w tym miejscu dodać, że wstęp do katalogu mediolańskiej wystawy rzeźb Lednickiej z 1926 roku, napisał Carlo Carrà ${ }^{10}$, a sama artystka, będąc w Italii, uczestniczyła w Międzynarodowej Wystawie Sztuki Religijnej w Padwie w 1931 roku $^{11}$. Sztuka religijna była obecna także w Polsce, stanowiąc naturalny element życia artystycznego II Rzeczypospolitej ${ }^{12}$. Widocznym przykładem tego zjawiska były urządzane wystawy sztuki religijnej ${ }^{13}$, a także narastająca w latach 30 . potrzeba zreformowania współczesnej polskiej sztuki kościelnej ${ }^{14}$.

Maryla Lednicka urodziła się w Moskwie w 1893 roku. Jej ojcem był Aleksander Lednicki - adwokat i działacz społeczny, blisko związany z kręgami postępoworewolucyjnymi. Matką rzeźbiarki była Maria Poczobutt-Odlanicka, pochodząca z mieszanej rodziny polsko-rosyjskiej. Talent rzeźbiarski ujawnił się u Lednickiej w wieku 13-14 lat, na zajęciach $\mathrm{z}$ modelowania w czasie nauki na moskiewskiej pensji u pani Wiaziemskiej. W tym czasie Lednicka całkowicie świadomie zainteresowała się tą właśnie gałęzią sztuki ${ }^{15}$. Zdolności artystyczne zostały przychylnie przyjęte przez rodzinę, ale niepotraktowane poważnie przez ojca, który nie przewidywał dla córki dalszej nauki oraz konieczności pracy zarobkowej. Był zwolennikiem tradycyjnego wykształcenia dla kobiet, tak więc i ich roli w społeczeństwie. Niebawem Lednicką wysłano do Warszawy na pensję Anieli Wereckiej, którą ukończyła w 1912 roku. Po powrocie do Moskwy jej zainteresowania rzeźbiarskie nie minęły i w tym samym roku rozpoczęła studia w Szkole Sztuk Pięknych pod kierunkiem, między innymi, Władimira Domogackiego ${ }^{16}$. Według relacji jej brata, siostra nie lubiła Rosji i marzyła o studiach w Paryżu, pod kierunkiem Émile Antoine'a Bourdelle'a ${ }^{17}$, który prowadził pracownię dla kobiet. Rok wcześniej z Moskwy wyjechała Wiera Muchina, która zaczęła

\footnotetext{
${ }^{9}$ Przykładem może być podpisany przez futurystów Manifest Sztuki Sakralnej, pierwotnie wydrukowany w „Gazetta del Popolo” (23.06.1931).

${ }^{10}$ Marie Lednicka-Szczytt. Mostra Personale, Milano 1926.

${ }^{11}$ Esposizione internazionale d'arte sacra cristiana moderna, 1931-1932, Padova 1931.

${ }^{12}$ Zob.: W. Skrodzki, Polska sztuka religijna 1900-1945, Warszawa 1989.

${ }^{13}$ Pierwsze istotne ekspozycje sztuki religijnej odbyły się jeszcze przed Wielką Wojną; zob.: O. Rudenko, Wystawa Liturgiczna we Lwowie 1909 roku wobec wspótczesnej sztuki kościelnej, Teka Komisji Polsko-Ukraińskich Związków Kulturowych 2007, s. 53-64; Pierwsza Wystawa współczesnej polskiej sztuki kościelnej im. Piotra Skargi w Krakowie, Kraków 1911. W dwudziestoleciu międzywojennym: Wystawa polskiej sztuki religijnej na Ślasku (katalog tymczasowy), Katowice 1931; Katalog wystawy sztuki religijnej i kościelnej w Częstochowie. Maj- wrzesień 1934, Warszawa 1934.

${ }^{14}$ K. Mitera, Ku odrodzeniu sztuki religijnej, Głos Plastyków 1934 nr 9-12, s. 139-143; Sz. Dettloff, Częstochowa. Wystawa Sztuki Religijnej i Kościelnej, Głos Plastyków 1934 nr 9-12, s. 185-186; O polskiej sztuce religijnej, red. J. Langman, Katowice 1932.

${ }^{15}$ W. Lednicki, Pamiętniki, t. 2, s. 293.

${ }^{16}$ Władimir Domogacki (1876-1939), rosyjski rzeźbiarz. Studiował na Uniwersytecie Moskiewskim (1897-1902). Pobierał także prywatne lekcje rzeźby u Siergieja Volnuchina. Odbył kilka podróży artystycznych do Paryża $(1896,1900,1907,1912)$ oraz Włoch (1901). Wykładał w Szkole Sztuki Stosowanej Stroganowa w Moskwie w latach 1908-1910 (obecnie Moskiewski Państwowy Artystyczno-Przemysłowy Uniwersytet imienia Sergieja Grigoriewicza Stroganowa). W latach 1923-1925 pracował w Galerii Trietiakowskiej (praca naukowa nad historią i teorią rzeźby oraz restauracja dzieł). Członek Moskiewskiego Związku Rzeźbiarzy w Moskwie. Tworzył przede wszystkim rzeźbę portretową (Franciszek Liszt, Karol Marx, Lew Totstoj, Portret syna), kobiece akty (Tors kobiecy, Kobieta, Amazonka) czy figurki zwierząt. Obecnie większość jego dorobku przechowywana jest w Galerii Trietiakowskiej w Moskwie.

${ }^{17}$ W. Lednicki, Pamiętniki, t. 2, s. 296.
} 
studia pod jego kierunkiem ${ }^{18}$. W tym samym czasie w pracowni rzeźbiarza studiowały też Polki: Jadwiga Bohdanowicz ${ }^{19}$, Janina Broniewska ${ }^{20}$, Luna Drexler ${ }^{21}$ czy Mika Mickun $^{22}$.

W 1913 roku Lednicka wyjechała do Paryża i rozpoczęła studia w Académie de la Grande Chaumiére, w pracowni Bourdelle'a — pedagoga zaangażowanego zarówno w naukę zawodu, jak i teorię rzeźby. Rodzina artystki miała sporo znajomych, przebywających ówcześnie w stolicy Francji, i młoda rzeźbiarka szybko zaaklimatyzowała się w środowisku kolonii polskiej. Bezpieczeństwo finansowe zapewniły jej środki materialne ojca. Wybuch I wojny światowej zaskoczył artystkę na wakacjach w rodzinnym majątku w Rosji.

Niewiele wiadomo o pierwszym paryskim roku studiów Lednickiej. W tym czasie nie wystawiała swoich prac na żadnym $\mathrm{z}$ tamtejszych Salonów ${ }^{23}$. Samodzielne życie $\mathrm{z}$ dala od Moskwy musiało ją pociągać, podobnie jak nauka pod kierunkiem Bourdelle'a. Świadczą o tym wspomnienia brata, który pisał, że siostra, będąc znowu w Rosji, tęskniła za życiem w Paryżu i mówiła tylko o powrocie do Francji ${ }^{24}$. Pod koniec roku 1917 Lednicka wyszła za mąż za przyjaciela rodziny, Władysława Niemirycz-Szczytta. Na związek sceptycznie patrzyli jej rodzice. Nie wiadomo, czy powodem był niechętny stosunek do zięcia, czy też fakt, że decyzja córki stała się szansą wyzwolenia spod wpływu ojca i usamodzielnienia Lednickiej. Szczytt miał kontakty ze środowiskiem lewicowym, co umożliwiło im otrzymanie paszportu na wyjazd do Paryża przez Skandynawię. Środki finansujące podróż otrzymali od ojca Lednickiej. Jednak próba dotarcia do Paryża nie powiodła się z powodu zakazu wjazdu, wydanego przez francuską misję wojskową. Małżeństwo spędziło kilka tygodni w Londynie, z którego w listopadzie 1918 roku przyjechali do Warszawy. W odrodzonej Polsce Lednicka nie czuła się jak u siebie, nie była też aktywna artystycznie. Odnotowano tylko jeden jej udział w Salonie Dorocznym TZSP ${ }^{25}$. Najpewniej, po dzieciństwie spędzonym w Rosji i studiach paryskich, Warszawa wydawała jej się artystyczną prowincją. W tym czasie jej męża zmobilizowano i uzyskał przydział do wojskowej komisji zakupów we Francji. Po niecałych trzech latach do Polski wrócił już tylko Szczytt. Wszystko wskazuje na to, że było to małżeństwo z rozsądku, które umożliwiło Lednickiej ucieczkę z Moskwy oraz uniezależnienie się od rodziny. Wychowana w przedrewolucyjnej Rosji, gdzie kobiety traktowano jako współuczestniczki w systemie kultury, Lednicka czuła się kobietą na wskroś nowoczesną, a niezależność podnosiła jej możliwości twórcze ${ }^{26}$. Co

${ }^{18}$ Dictionary of women artists, t. 2: Artists J-Z, red. D. Gaze, London-Chicago 1997, s. 995.

19 Jadwiga Bohdanowicz, [w:] Stownik artystów polskich $i$ obcych $w$ Polsce działających: malarze, rzeźbiarze, graficy, t. 1, Wrocław 1971, s. 200.

${ }^{20}$ Janina Broniewska, [w:] Stownik artystów polskich, s. 248.

${ }^{21} \mathrm{~J}$. Biriulow, Rzéba lwowska od połowy XVIII wieku do 1939 roku: od zapowiedzi klasycyzmu do awangardy, Warszawa 1997, s. 192.

${ }^{22}$ K. Moisan-Jabłońska, Mika Karolina Mickun - zarys biografii i twórczości, Biuletyn Historii Sztuki 1996 nr 1-2, s. 33-45.

${ }^{23}$ Por.: H. Bartnicka-Górska, J. Szczepińska-Tramer, $W$ poszukiwaniu światła, kształtu i barw. Artyści polscy wystawiający na Salonach paryskich w latach 1884-1960, Warszawa 2005.

${ }^{24}$ W. Lednicki, Pamiętnik, t. 2 s. 293, 316.

${ }^{25}$ Instytut Sztuki PAN, Warszawa, Materiały Słownika Artystów Polskich; Odnotowany został jej udział w Salonie Dorocznym TZSP w 1919 roku.

${ }^{26}$ W Rosji pierwsze głosy dotyczące praw kobiet oraz możliwości ich edukacji pojawiły się w połowie XIX wieku i, co wyróżniało ten kraj na tle ówczesnej epoki, pochodziły one z kręgów elit państwowych oraz wyższych sfer; zob.: L. Engelstein, Between Old and New: Russia's Mo- 
ciekawe, jej wygląd zewnętrzny nie zdradzał wykonywanego zawodu. Na fotografiach $\mathrm{z}$ lat 20. widać drobną kobietę $\mathrm{w}$ doskonale skrojonych ubraniach, często $\mathrm{w}$ futrze. Elegancję Lednickiej podkreślały konfekcyjne dodatki w postaci torebki i dopasowanego kapelusika, spod którego wystawały starannie zaczesane włosy (il. 1, 2, 3). W artykułach prasowych recenzenci najpierw zwracali uwagę na wygląd Lednickiej, a potem na jej dzieła.

Kto nie widział Maryli Lednickiej przy pracy, kto znał ją tylko z salonu [...] ten nie mógł uwierzyć, że jej kruche kobiece ręce potrafią tak sprawnie porać się z marmu$\mathrm{rem}^{27}$.

Rzeźbiarstwo, uchodzące za pracę brudną i ciężką fizycznie, nie pasowało do tej „paryskiej chłopczykowatej rzeźbiarki, jakby zagubionej wśród wielkich biustów z drzewa i marmuru”, tej „laleczki, modnie ustylizowanej na garsonkę"28. Rzeźbiarka do końca życia zachowała styl elegantki. Wacław Lednicki, wspominając siostrę na kilka lat przed jej śmiercią, pisał: „,malutka i szczupła, idąca szybko na swoich wysokich obcasach"29.

W Paryżu artystka kontynuowała naukę pod kierunkiem Bourdelle'a. Już w 1920 roku wystawiła pięć rzeźb na Salonie Jesiennym. Ich tytuły wskazują, że były to raczej formalne rozwiązania rozmaitych problemów rzeźbiarskich, aniżeli świadome artystycznie kompozycje ${ }^{30}$. W roku następnym, na tym samym Salonie, Lednicka pokazała już tylko dwie prace - marmurowy Biust pani Chruszczow i wykonaną w drewnie dębowym Madonnę (il. 4). Najpewniej jednym z czynników, warunkujących skromną ilość dzieł na ekspozycji, był czas, jaki rzeźbiarka poświęciła na staranne opracowanie trudnych w obróbce materiałów. Salon w 1921 roku należy uznać za szczególny, gdyż to wtedy w twórczości artystki pojawiła się pierwsza, znana rzeźba o charakterze religijnym. Hieratyczna postać Madonny została ujęta frontalnie. Gdyby nie delikatne odchylenie głowy i ułożenie dłoni, jej figura byłaby zupełnie symetryczna. Masywna bryła rzeźby odznacza się rytmicznością wyartykułowanych elementów: dwóch stylizowanych i ciężko opadających na ramiona warkoczy oraz fałdów szaty,

dern Women, [w:] Amazons of the Avant-Garde. Alexandra Exter, Natalia Goncharova, Liubov Popova, Olga Rozanova, Varvara Stepanova, and Nadezhda Udaltsova, red. J. E. Bowlt, M. Drutt, Berlin, 2000, s. 61. Rosjankom bardzo wcześnie umożliwiono podnoszenie swoich kwalifikacji zawodowych. W dużych ośrodkach miejskich specjalistyczne kursy dla kobiet istniały już w latach 70. XIX wieku. Do 1914 roku 30 procent wszystkich studentów wyższych uczelni stanowiły kobiety; zob.: Ch. Johanson, Women's Struggle for Higher Education in Russia, 1855-1900, Kingston-Montreal 1987. W drugim dziesięcioleciu XX wieku kobieca aktywność na polu sztuki nie była odosobnionym zjawiskiem. Akademia Sztuk Pięknych w Petersburgu przyjmowała kobiety od 1871 roku, niedługo później podążył za nią moskiewski Instytut Malarstwa, Rzeźby i Architektury. Dzięki tym instytucjom już w latach 80. XIX wieku zaistniało pierwsze pokolenie profesjonalnie wykształconych kobiet-malarek. Jeszcze przed wybuchem Wielkiej Wojny ówczesna prasa zwróciła uwagę na istotną rolę artystek w świecie sztuki; zob.: Amazons of the Avant-Garde, s. 22, 27.

${ }^{27}$ T. B. Spitzer, Maryla Lednicka, Orzeł Biały 1947 nr 39, s. 4.

${ }^{28}$ Instytut Sztuki PAN, Warszawa Zbiory Specjalne, Archiwum Wacława Husarskiego, nr inw. 1404, teczka nr 11, Lal-Less, wycinek prasowy; Or, Polska rzeźbiarka w Paryżu, Kurier Polski 1927 nr 195.

${ }^{29}$ W. Lednicki, In memoriam Maryla Lednicka, San Francisco 1950, s. 1.

30 Tytuły prac Lednickiej wystawionych na Salonie Jesiennym w 1920: Glowa kobiety (brąz), Kobieta skulona (brąz), Ekstaza (płaskorzeźba), Tancerka (motyw dekoracyjny), Tancerz (motyw dekoracyjny), za: H. Bartnicka-Górska, J. Szczepińska-Tramer, W poszukiwaniu światta. 
której monotonnie kształtowana draperia uzyskuje zupełną autonomię. W oczach polskich korespondentów w Paryżu, Madonna Lednickiej posiadała cechy „słowiańskości” ${ }^{31}$ i szybko została przemianowaną na „Polską Madonnę, która wywoływała wspomnienia gotyku nadwiślańskiego" ${ }^{\text {,2 }}$. Chociaż podobieństwo do gotyckich Madonn i rzeźby ludowej wyraźnie się tu nasuwa ${ }^{33}$, to wątpliwe, żeby Lednicka aż tak dobrze znała sztukę polską, by móc się na niej wzorować. W kraju spędziła zaledwie kilka lat swojego życia. Inspiracje i sposób użycia środków formalnych wskazują na korzystanie w pracy ze wskazówek Bourdelle’a, który głosił, że „dzieło skomponowane powinno być zdyscyplinowane, to znaczy, że szczegół powinien odpowiadać całości, a całość szczegółowi”, a „wszystkie części dzieła muszą być logicznie zestawione, nic nie powinno być pozostawione przypadkowi" ${ }^{\text {"34 }}$. Mistrz należał do przedstawicieli nowego klasycyzmu w rzeźbie, czyli artystów stojących w opozycji do spadku pozostawionego przez Augusta Rodina, jego nadmiernie rozbitej formy rzeźbiarskiej obciążonej ładunkiem ekspresji ${ }^{35}$. Bourdelle propagował powrót do cech stanowiących istotę klasycznej rzeźby, to jest monumentalności, tektoniki, zwartej i jasno określonej struktury oraz bezpośredniego kucia w materiale. Ta metoda pracy będzie dominować w twórczości Lednickiej. Autor paryskiego Pomnika Adama Mickiewicza twierdził, że „wszystko co jest syntezą, jest archaizmem"36. Praźródłem sztuki była dla niego szeroko pojęta archaizacja, którą odnajdywał zarówno w rzeźbie asyryjskiej, egipskiej, wczesnoantycznej, jak i romańskiej czy gotyckiej. Rzeźbiarz nie wywierał bezwzględnego wpływu na swoich wychowanków. Mówił: „Daję im swobodę, nie staram się na nich wpływać, a chcę ich uzbroić w zdolności tworzenia według własnego usposobienia"37. Ta postawa spowodowała, że z jego pracowni wyszły pokolenia jednostek o zupełnie odmiennych twórczo temperamentach — Germaine Richier, wyżej wspomniana Muchina czy Alberto Giacometti. Nauka Bourdelle'a nie kończyła się w pracowni, bo często organizował wykłady o sztuce $\mathrm{w}$ swoim domu ${ }^{38}$, a także wspólne wyjścia do muzeów ${ }^{39}$. Za motto jego uczniów można uznać zdanie: „,należy odczytywać przeszłość, a nie naśladować jej gesty" 40 . Prawdopodobnie to wizyty w Luwrze i obecne tam arcydzieła od-

${ }^{31}$ Paryski Salon Jesienny, Świat 1921 nr 51, s. 10.

${ }^{32}$ [J. W. Jarociński] W. George, Polacy w salonie jesiennym Paryża, Wiadomości Literackie 1924 nr 49, s. 4.

${ }^{33}$ M. Dąbrowska-Szelągowska, Rzeźba polska okresu międzywojennego: wptywy francuskie a poszukiwanie niezależności, [w:] Między Polska a światem. Od średniowiecza po lata II wojny światowej, red. M. Morka, P. Paszkiewicz, Warszawa 1993, s. 314.

34 Nauki Bourdelle'a (wypowiedzi zebrane przez Marie Dormoy), Głos Plastyków 1937/1938 nr 1-7, s. 62-63.

${ }^{35}$ M. Szelągowska, $W$ cieniu mistrzów francuskich — polska rzeźba nowego klasycyzmu, [w:] Sztuka lat 1905-1923. Malarstwo - rzeźba - grafika - krytyka artystyczna. Materiały z konferencji naukowej, red. M. Geron, J. Malinowski, Toruń 2006, s. 32.

${ }^{36}$ A. Bourdelle, Ecrits sur l'art et sur la vie, illustrés des dessins de l'auteur, Paris 1955, s. 67, cyt. za: M. Dąbrowska-Szelągowska, Rzeźba polska okresu międzywojennego.

${ }^{37}$ A. Bourdelle, O malarstwie, wywiad A. Warnod z Bourdellem, cyt. za: M. Dąbrowska-Szelągowska, Rzeźba polska okresu międzywojennego, s. 312.

${ }^{38}$ M. [Dąbrowska-]Szelągowska, Muzeum Bourdelle'a w Paryżu. Między marzeniem a realizacja, [w:] Pracownia $i$ dom artysty $w$ XIX i XX wieku. Mitologia i rzeczywistość, red. A. Pienkos, Warszawa 2002, s. 118

${ }^{39}$ Wiadomo o tym dzięki relacji innej polskiej rzeźbiarki, która uczyła się w pracowni Bourdelle'a; zob.: Z. Rotherowa, O Janinie Broniewskiej, Nowiny Literackie 1948 nr 8, s. 2.

${ }^{40}$ Cyt. za: M. Szelągowska, W cieniu mistrzów francuskich, s. 118. 
działały na Lednicką i jej recepcję rzeźby. Korzenie figury Madonny tkwią w kręgu archaicznej sztuki greckiej i to tam znajduje się jej prototyp — schematyczny, choć niepozbawiony stylizacji posąg kory. Frontalnie ustawiona Madonna ubrana jest w długą szatę, będącą dalekim echem chitonu greckiego. Młoda dziewczyna z delikatnym uśmiechem na twarzy i dekoracyjnie potraktowanych włosach przywołuje na myśl także posągi kariatyd z greckiego Erechtejonu, które artystka mogła zobaczyć podczas podróży do Grecji wraz ze swoją rodziną na Wielkanoc $1909 \mathrm{roku}^{41}$. Zapewne widziała także Salę Kariatyd (Salle des Caryatides), jedną z galerii muzeum w Luwrze. Do tego motywu rzeźbiarka powróci kilka lat później, tworząc cztery posągi kariatyd dla włoskiego Pawilonu Spożywczego na targach w Mediolanie w 1928 roku (il. 5).

Na Salonie Jesiennym, w roku 1922, Lednicka wystawiła tylko jedną pracę Czarnego Aniota (il. 6) wykonanego w drewnie. Ów rok był dla artystki trudnym okresem ze względu na przewlekłą chorobę, a potem śmierć matki. Czarny Anioł w niczym nie przypomina niewinnego posągu Madonny. Kompozycja rzeźby zamknięta jest w trójkącie prostokątnym, w którym jedną przyprostokątną stanowi tułów postaci i bardzo schematycznie potraktowane skrzydło, a druga to linia bioder i klęczących kolan, zamkniętych w bryle walca, ożywionego płytkimi nacięciami wzdłuż całości. Zastosowany przez Lednicką gest dłoni anioła wywołuje dwa rodzaje skojarzeń. Mogą to być dłonie składane do modlitwy albo zasłaniające oczy. Uwagę zwracają skrajnie zredukowane środki plastyczne i wyzbycie się dekoracyjnych detali. Twarz Anioła upodobniona została do rzeźb egipskich władców o regularnych rysach, wysokim czole, prostym nosie i gałkach ocznych oprawionych dekoracyjną linią. Oszczędne, prawie beznamiętnie nacięcia dolnej partii ciała kojarzą się z głowicami egipskich kolumn palmowych, które Lednicka również mogła widzieć w Luwrze. Czarny Anioł jest chyba jedynym dziełem artystki, w którym wyczuwa się dążenie do nadania bryle abstrakcyjnej formy.

W ciągu kilku kolejnych lat artystka nie powracała do zagadnień rzeźby religijnej. Spowodowane to było przede wszystkim wyjazdem do Włoch w 1924 roku, gdzie osiadła na kilka następnych lat. Tworzyła wtedy na zamówienie włoskich elit portrety i biusty, dzięki którym zyskiwała coraz większy prestiż jako rzeźbiarka. W 1928 roku zaoferowano jej współpracę przy projektowaniu wyżej wspomnianego Pawilonu Spożywczego w Mediolanie oraz uczestnictwo w weneckim Biennale. W tym samym roku Lednicką zaproszono na członka jury paryskiego Salonu Jesiennego. Było to niewątpliwie wyróżnienie, zważywszy na to, że była kobietą i do tego cudzoziemką. Sama nadal wystawiała na tymże Salonie, pokazując publiczności Anioła (il. 7), formalnie bliskiego kolejnej rzeźbie pod tytułem Klęczacy anioł (il. 8), wystawionej na wspomnianej już Międzynarodowej Wystawie Sztuki Religijnej w Padwie. Oba posągi nawiązują do tradycji sztuki średniowiecznej. Lednicka podczas kształtowania figur ponownie ograniczyła środki formalne. Starannie zamknęła gładko modelowane kontury Anioła, przez co jego bryła zyskała zwartość kompozycyjną. Z tułowia wyrastają dwa dosyć masywne i surowo ciosane skrzydła, które przywodzą na myśl otwarty średniowieczny dyptyk. Spokojny rysunek szat nie tworzy żadnych draperii na ciele. Lewa ręka naturalnie układa się wzdłuż tułowia, tymczasem prawa jest zgięta w łokciu i trzyma sztywno wyciągniętą dłoń. Nieznacznie odchylona głowa o klasycznym profilu twarzy i krótko ściętych włosach nasuwa skojarzenia z francuską rzeźbą portalową gotyckich katedr. Jednak Anioł Lednickiej uzyskał autonomię i nie jest związany z tłem architektonicznym, przez co samodzielnie i swobodnie egzystuje w przestrzeni. Mode-

${ }^{41}$ W. Lednicki, Pamiętniki, t. 1, s. 23. 
lunek Klęczącego Anioła jest bardziej subtelny, a kontur sylwetki wyznacza ozdobna linia. Figurę ożywiają skrzydła oraz włosy, które wydają się uformowane przez wiatr. Delikatne rysy twarzy przypominają śmiejącego się anioła z portalu katedry w Reims.

W 1928 roku na Biennale w Wenecji, Lednicka wystawiła klęczącego w skupieniu i zatopionego w modlitwie Świętego Franciszka (il. 9), różniącego się od wszystkich wcześniejszych religijnych dzieł Lednickiej, bo potraktowanego niezwykle realistycznie - zarówno w dopracowaniu szczegółów twarzy i dłoni, jak i draperiach habitu. Poprzez miękką linię rzeźbiarską artystka uzyskała efekt wyciszenia, towarzyszącego modlitwie świętego.

Ówczesna prasa, zarówno polska jak i zagraniczna, różnie podchodziła do religijnych figur Lednickiej. Dziennikarze baczniejszą uwagę zwracali na portrety jej autorstwa, zresztą bardzo wysoko oceniane ${ }^{42}$. Wśród polskich korespondentów w Paryżu najbardziej przychylna artystce była osiadła we Francji, aktywna w środowisku kolonii polskiej i współpracująca z warszawskim Światem oraz z czasopismami francuskimi, Maria Kasterska. Opinie na temat sztuki Lednickiej pojawiały się w tekstach historyka literatury i publicysty Zygmunta Lubicz-Zalewskiego oraz historyka sztuki, literata i pisarza Edwarda Woronieckiego ${ }^{43}$. Krytycy z jednej strony chwalili rytmiczność kompozycji rzeźb oraz dobrze przemyślane, bo współgrające ze sobą płaszczyzny, ale $\mathrm{z}$ drugiej zarzucali jej nadmierną stylizację i sięganie do wzorów obcych stylistyk ${ }^{44}$. Ocena dzieł wynikała z konserwatywnego podejścia do sztuki obu wyżej wymienionych recenzentów i skłonności do wyróżniania tych artystów, których twórczość zamykała się w specyficznie ,polskim” kręgu kulturowym. Tymczasem Lednicka nie była w swojej sztuce konsekwentna — raz ,zdejmowała okulary greckie" ${ }^{, 45}$ i zrywała z europocentryczną tradycją, a niedługo później do niej wracała. W całej swej twórczości Lednicka odwoływała się od różnych kulturowych źródeł. Rzeźba religijna mogła być dla niej artystyczną odskocznią, która umożliwiła eksperymenty z formą.

Na początku lat 30. rzeźbiarka wyjechała do Stanów Zjednoczonych. Wiadomo, że wcześniej kilkukrotnie odbyła podróż do Nowego Jorku, co odnotowała tamtejsza prasa $^{46}$. W 1934 roku Lednicka miała już indywidualną ekspozycję w Wildenstein

${ }^{42}$ M. Kasterska, Tegoroczny Salon Jesienny w Paryżu, Świat 1924 nr 2, s. 3; E. Woroniecki, Sztuka polska w salonach paryskich, Tygodnik Ilustrowany $1925 \mathrm{nr}$ 20, s. 395; R. Ordyński, Polska rzeźbiarka w Mediolanie, Wiadomości Literackie 1926 nr 15, s. 1; M. Kasterska, Maria Szczytt-Lednicka, Bluszcz 1928 nr 41, s. 11-12; Instytut Sztuki PAN, Warszawa, Zbiory Specjalne, Archiwum Wacława Husarskiego, nr inw. 1404, teczka nr 11, L. H. M., Rzeźby Szczytt-Lednickiej (niezidentyfikowany wycinek prasowy). Pochlebne recenzje twórczości portretowej Lednickiej nie oznaczały, że jej rzeźby religijne nie zostały dostrzeżone. Doskonałymi przykładami są prace Czarny Anioł i Święty Franciszek, obie wyróżnione złotym medalem na Międzynarodowej Wystawie Sztuki Religijnej w Padwie.

${ }^{43}$ A. Wierzbicka, Artyści polscy w Paryżu. Antologia tekstów o polskiej kolonii artystycznej czynnej w Paryżu w latach 1900-1939, Warszawa 2008, s. 16.

${ }^{44}$ Por.: E. Woroniecki, Artyści polscy w paryskim salonie [Jesiennym], Tygodnik Ilustrowany $1924 \mathrm{nr}$ 7, s. 101; tenże, Polacy w Salonie Tuileryjskim, Tygodnik Ilustrowany 1924 nr 37, s. 603-604; [Z. Lubicz Zalewski] Z.L.Z., Od niedzieli do niedzieli, Kurier Warszawski 1924 nr 59, s. 10; tenże, Polscy plastycy w Paryżu, Kurier Warszawski 1922, nr 93, s. 3.

${ }^{45}$ Cyt. za: H. Moore, O pojmowaniu rzeźby, [w:] Artyści o sztuce. Od van Gogha do Picas$s a$, red. E. Grabska, H. Morawska, Warszawa 1963, s. 498.

${ }^{46}$ Por.: NN, Sculptress here, Brooklyn Daily Eagle (New York) 1932 nr 344, s. 12; NN, McAdoo, Back from Russia Indorses Recognition Move, New York Post 1933 nr 290, s. 3. 
Gallery ${ }^{47}$, rok później wzięła udział w wystawie rzeźby w Brooklyn Museum ${ }^{48}$, a w 1939 roku miała kolejny indywidualny pokaz prac w Julien Levy Gallery ${ }^{49}$. Chwilę wcześniej została członkiem Gildii Rzeźbiarzy (Sculptors Guild). Było to zaszczytne wyróżnienie, gdyż otrzymanie zaproszenia do stowarzyszenia musiało być podparte wyjątkowymi zdolnościami rzeźbiarza oraz profesjonalnym podejściem do własnej pracy $^{50}$.

Aktywność zawodową i pasmo sukcesów Lednickiej przerwała II wojna światowa. W tym czasie artystka nie miała zamówień prywatnych, a przyzwyczajona do życia w luksusowych warunkach, nie mogła się pogodzić z koniecznością podjęcia innej pracy zarobkowej. Rzeźba zawsze należała do kosztownych gałęzi sztuki, a jednym ze znaków rozpoznawczych biustów i portretów Lednickiej były szlachetne materiały, z jakich korzystała, między innymi marmur biały, różowy, drewno mahoniowe czy palisandrowe. Wśród nielicznych ówczesnych zleceń znalazły się zamówienia kościelne. Nic nie wiadomo o wcześniejszych realizacjach sakralnych artystki i wszystko wskazuje na to, że prace stworzone w Stanach Zjednoczonych to jej pierwsze rzeźby o funkcjach dewocyjnych. Koncepcje przedstawieniowe niżej wymienionych posągów były podyktowane wskazówkami zamawiającego, a ich zachowawczość i stereotypowość z pewnością doskonale zaspokajała zapotrzebowanie wiernych. Figury świętych w żadnym szczególe nie wychodziły poza religijną konwencję ikonograficzną i swoją schematycznością powtarzały wszystkie ich wcześniejsze ujęcia. Tak ukazany został Święty Antoni z Padwy, wyrzeźbiony na zlecenie kościoła Świętej Brygidy w Peapeck w New Jersey (il. 10). Lednicka stworzyła posąg w powszechnie występującym wapieniu, materiale twardym, choć łatwym w obróbce. Wybór tworzywa dyktowany był najpewniej skromnymi środkami finansowymi kościoła. Wizerunkowi franciszkanina, trzymającego na rękach Dzieciątko Jezus, można zarzucić błędy anatomiczne, niedopracowanie bryły i naiwność. Podobnie ujęty został Święty Bernard, przeznaczony do kaplicy w szkole świętego Bernarda w New Jersey (il. 11). Warto wspomnieć o rzeźbie Marii z Dzieciątkiem (il. 12) dla kościoła Zmartwychwstania w Nowym Jorku. Posąg w niczym nie przypomina popularnych wizerunków, nawiązujących do tradycji Pięknych Madonn. Stylistycznie można go powiązać z ikonografią Matki Boskiej Bolejącej. Surowo cięta bryła umożliwiła rzeźbiarce umiejętnie wydobyć ekspresyjne walory użytego drewna. Szczupły tułów Madonny okrywa pionowo żłobiona szata, która upodabnia figurę do trzonu kolumny. Głowa jest nieosłonięta żadną materią, stąd widoczne jest wysokie czoło i dekoracyjnie wystylizowane, gładko ułożone włosy. Pochylona twarz Marii wyraża sprzeczne emocje — spokój jest tu splątany ze smutkiem i zrezygnowaniem, ale też z żarliwą pobożnością. Podobną ekspresję Lednicka osiągnęła w rzeźbie Duch Medytacji (il. 13), która obecnie znajduje się w Muzeum w Newark

\footnotetext{
${ }^{47}$ NN, Attractions in the Galleries, The New York Sun 1934 nr 88, s. 15; NN, Sculptures by Maryla Lednicka, Brooklyn Daily Eagle (New York) 1934 nr 355, s. 33.

48 Brooklyn Museum Archives, Records of the Department of Public Information, Nowy Jork, Press releases, 1931-1936. 04-06_1935, 063. Sculpture. A Group Exhibition, May 3, 1935 through October 6, 1935.

${ }^{49}$ Philadelphia Museum of Art Archives, Filadelfia, Julien Levy Gallery Records, Series III. Exhibition announcements and other ephemera, 1931-1948.

${ }^{50}$ Smithsonian Archives of American Art, Waszyngton D.C., Sculptors Guild Records, series 3: Artists files, circa 1938-1979 (Boxes 4, 9, OV 10; 0,5 linear feet). W 1942, Lednicka wzięła udział w zorganizowanej przez Sculptors Guild wystawie „Sculpture of Freedom” w Rockefeller Center w Nowym Jorku; zob.: Sculptors Guild presents: Sculpture of Freedom. Sept. 15 - Oct. 15. 1942, New York 1942.
} 
w New Jersey. Figura wykonana jest w drewnie i ustawiona na postumencie. Postać ukazano w długiej szacie, spod której lekko wysunięta jest prawa stopa. Lednicka powróciła tu do znanego z wcześniejszych prac gestu zgiętych w łokciach rąk i sztywno wyprostowanych dłoni. Od strony kompozycyjnej zabieg ten nadaje rzeźbie równowagę, ale można go odczytać jako gest nauczania i w takim rozumieniu powiązać dzieło $\mathrm{z}$ tradycją symboliczno-dydaktycznych rzeźb portali romańskich. Postać wydaje się nie mieć płci, tak zresztą jak anioły Lednickiej. Nie wiadomo, czy Duch medytacji powstał na zamówienie kościelne, czy raczej był wynikiem osobistej wizji artystki. Jeśli tak, to rzeźba ta jest ostatnią znaną pracą Lednickiej o charakterze religijnym. Powróciła w niej do swoich wcześniejszych aniołów, emanujących religijnością jako duchowym przeżyciem.

W rzeźbach sakralnych Lednickiej łatwo wychwycić regres twórczy. Prace są zachowawcze, wyglądają na pospiesznie wykonane i stąd też niedopracowane. Istnieje prawdopodobieństwo, że artystce takiego rodzaju zamówienia po prostu nie odpowiadały, gdyż kanon przedstawieniowy dyktowany był poniekąd z góry i kierowany do innego rodzaju publiczności niż była przyzwyczajona. Nie można jednak zarzucić Lednickiej braku konsekwencji twórczej. Jej artystyczna wizja była bardzo spójna: wydłużone figury świętych zostały ustawione na postumentach, a pionowe drapowania ich szat przypominały kanelury, upodabniając posągi do greckich kolumn, obecnych w twórczości Lednickiej od lat 20.

Wiesław Juszczak zanotował, że w mniej udanych dziełach sakralnych szuka się winy albo w mecenacie, albo w braku pobożności artysty tworzącego dzieło ${ }^{51}$. Tłumacząc to zjawisko, powołał się na Mircea Eliadego, według którego trzeba takie prace rozpatrywać według ich warunków istnienia, a tym warunkiem jest przestrzeń kultowa. Tak więc należy rozpatrywać je w skali religijnej, która nie da się sprowadzić do żadnej fizjologii, psychologii, socjologii, ekonomii czy sztuki właśnie, bo zgubi się ich charakter sakralny ${ }^{52}$. W przypadku rzeźb sakralnych Lednicka zwróciła się do żarliwej religijnie sztuki średniowiecza, której funkcją było uobecniane. W takich wizerunkach można sobie pozwolić na surowe ciosanie w drewnie i anatomiczne błędy. Nie bez znaczenia na wybór stylistyki rzeźb wpłynęła słaba forma psychiczna oraz będące w coraz gorszym stanie zdrowie artystki, a także brak środków finansowych. Najprawdopodobniej wszystkie te czynniki doprowadziły rzeźbiarkę do samobójstwa ${ }^{53}$.

Baudelaire pisał o „trudności w stworzeniu rzeźbiarskiego [...] czyli obiektywnie istniejącego w przestrzeni, ekwiwalentu ulotnej, romantycznej wizji, ${ }^{\text {"5 }}$. Rzeźby aniołów i świętych, tworzone zarówno na zamówienia kościelne jak i kreowane z wewnętrznej potrzeby ich twórcy, należą do tematów ryzykownych artystycznie, przy których łatwo popaść w nawykowe interpretacje i popularne klisze. Lednicka z różnym skutkiem rzeźbiła swoje niematerialne „byty”. Jej prace można osadzić poza oficjalnymi formami kultu jako rzeźby „religijności bezwyznaniowej”,55. Co prawda ta strategia pomogła artystce uniknąć śmieszności religijnego kiczu, tak często towarzyszącego

${ }^{51}$ W. Juszczak, Czy istnieje mistyczna sztuka, [w:] Sacrum i sztuka, oprac. N. Cieślińska, Kraków 1989, s. 149.

52 M. Eliade, Traktat o historii religii, Warszawa 1966, s. 1.

${ }^{53}$ Artystka popełniła samobójstwo 25 maja 1947 roku.

${ }^{54}$ Cyt. za: P. Szubert, Wśród figur, [w:] Figura w rzeźbie polskiej XIX i XX wieku, Warszawa 1999, s. 25.

${ }^{55}$ E. Wolicka, Sacrum i sztuka - punkty zapalne sporu, Znak 1991 nr 12, s. 43. 
figurkom świętych i aniołów, ale nie wniosła żadnego nowatorstwa w kanonie wielkiej tradycji sztuki sakralnej.

Rzeźby Lednickiej warte są uwagi. Tworzone trochę na marginesie twórczości, często niepozbawione naiwnej metafory. Mogą jednak więcej mówić o upodobaniach rzeźbiarskich artystki niż jej, doskonałe w swej formie, portrety. Wart podkreślenia jest fakt, że Lednicka nigdy nie popadła w żadną manierę i jako artystka rozwijała się do końca życia. Choć zawsze w znaczącym stopniu korzystała z ikonograficznych konwencji, to potrafiła zinterpretować sporą ilość stylistyk formalnych, tak zwanych ówcześnie „archaizmów” sztuki egipskiej, starogreckiej i średniowiecznej. Nigdy nie tworzyła rzeźby monumentalnej czy pełnej dynamizmu jak Bourdelle. Realizowała się w małej i naturalnej skali. Prace jej autorstwa są ascetyczne, a przez to zwarte i pozbawione narracji. Uproszczone, choć czytelne kompozycje i jasno określone powierzchnie, świadczą o doskonałym warsztacie rzeźbiarskim i szerokiej skali umiejętności. Lednicka przejęła od swego mistrza te walory, które najlepiej odpowiadały jej aspiracjom artystycznym oraz najpełniej odzwierciedlały twórczy temperament.

\section{LITERATURA}

Instytut Sztuki PAN, Warszawa, Materiały Słownika Artystów Polskich;

Instytut Sztuki PAN, Warszawa Zbiory Specjalne;

Brooklyn Museum Archives, Nowy Jork;

Philadelphia Museum of Art Archives, Filadelfia;

Smithsonian Archives of American Art, Waszyngton D.C.

W. Bałus, Sztuka - idea - sacrum. Uwagi o XIX-wiecznych korzeniach wspótczesnej sytuacji sztuki sakralnej, Znak $1991 \mathrm{nr}$ 12;

H. Bartnicka-Górska, J. Szczepińska-Tramer, $W$ poszukiwaniu światła, ksztattu i barw. Artyści polscy wystawiajacy na Salonach paryskich w latach 1884-1960, Warszawa 2005;

J. Biriulow, Rzeźba lwowska od połowy XVIII wieku do 1939 roku: od zapowiedzi klasycyzmu do awangardy, Warszawa 1997;

Jadwiga Bohdanowicz, [w:] Stownik artystów polskich i obcych w Polsce działajacych: malarze, rzeźbiarze, graficy, t. 1, Wrocław 1971;

A. Bourdelle, Ecrits sur l'art et sur la vie, illustrés des dessins de l'auteur, Paris 1955;

Janina Broniewska, [w:] Stownik artystów polskich i obcych w Polsce dziatajacych: malarze, rzeźbiarze, graficy, t. 1, Wrocław 1971;

M. [Dąbrowska-]Szelągowska, Muzeum Bourdelle'a w Paryżu. Między marzeniem a realizacja, [w:] Pracownia i dom artysty w XIX i XX wieku. Mitologia i rzeczywistość, red. A. Pienkos, Warszawa 2002;

-, Rzeźba polska okresu międzywojennego: wplywy francuskie a poszukiwanie niezależności, [w:] Między Polska a światem. Od średniowiecza po lata II wojny światowej, red. M. Morka, P. Paszkiewicz, Warszawa 1993;

—, W cieniu mistrzów francuskich — polska rzeźba nowego klasycyzmu, [w:] Sztuka lat 19051923. Malarstwo - rzeźba - grafika - krytyka artystyczna. Materiały z konferencji naukowej, red. M. Geron, J. Malinowski, Toruń 2006;

Sz. Dettloff, Częstochowa. Wystawa Sztuki Religijnej i Kościelnej, Głos Plastyków 1934 nr 9-12;

Dictionary of women artists, t. 2: Artists J-Z, red. D. Gaze, London-Chicago 1997;

M. T. Diupero, Bourdelle w kręgu polskim, [w:] Paryż i artyści polscy 1900-1918. Wokół E.-A. Bourdelle'a, [kat. wystawy]. Muzeum Narodowe w Warszawie, 18 lutego-27 marca 1997. Koncepcja wystawy i katalog E. Grabska, Warszawa 1997;

M. Eliade, Traktat o historii religii, Warszawa 1966; 
L. Engelstein, Between Old and New: Russia's Modern Women, [w:] Amazons of the AvantGarde. Alexandra Exter, Natalia Goncharova, Liubov Popova, Olga Rozanova, Varvara Stepanova, and Nadezhda Udaltsova, red. J. E. Bowlt, M. Drutt, Berlin 2000;

Esposizione internazionale d'arte sacra cristiana moderna, 1931-1932, Padova 1931;

A. Gleizes, Art et religion. Art et science. Art et production, Chambéry 1970;

-, Posłannictwo twórcze czlowieka $w$ dziedzinie plastyki, Warszawa 1927;

H. Goodwin, The Harmonious Sculpture of Maryla Lednicka, The Polish Review 1946 nr 16;

I. Jabłowska, Artystka polska we Włoszech. Interview z p. Marja Szczytt-Lednicka, Kobieta współczesna $1933 \mathrm{nr} 33$;

[J. W. Jarociński] W. George, Polacy w salonie jesiennym Paryża, Wiadomości Literackie 1924 nr 49;

Ch. Johanson, Women's Struggle for Higher Education in Russia, 1855-1900, KingstonMontreal 1987;

W. Juszczak, Czy istnieje mistyczna sztuka, [w:] Sacrum i sztuka, oprac. N. Cieślińska, Kraków 1989 ;

M. Kasterska, Maria Szczytt-Lednicka, Bluszcz $1928 \mathrm{nr} 41$

—, Tegoroczny Salon Jesienny w Paryżu, Świat 1924 nr 2;

Katalog wystawy sztuki religijnej i kościelnej w Częstochowie. Maj-wrzesień 1934, Warszawa 1934;

W. Lednicki, In memoriam Maryla Lednicka, San Francisco 1950;

—, Pamiętniki, t. 1, Londyn 1963;

-, Pamiętniki, t. 2, Londyn 1967;

[Z. Lubicz Zalewski] Z.L.Z., Od niedzieli do niedzieli, Kurier Warszawski 1924 nr 359;

—, Polscy plastycy w Paryżu, Kurier Warszawski $1922 \mathrm{nr}$ 93;

Marie Lednicka-Szczytt. Mostra Personale, Milano 1926;

K. Mitera, Ku odrodzeniu sztuki religijnej, Głos Plastyków 1934 nr 9-12;

K. Moisan-Jabłońska, Mika Karolina Mickun - zarys biografii i twórczości, Biuletyn Historii Sztuki 1996 nr 1-2;

H. Moore, O pojmowaniu rzeźby, [w:] Artyści o sztuce. Od van Gogha do Picassa, red. E. Grabska, H. Morawska, Warszawa 1963;

Nauki Bourdelle'a (wypowiedzi zebrane przez Marie Dormoy), Głos Plastyków 1937/1938 nr 1-7;

NN, Attractions in the Galleries, The New York Sun 1934 nr 88;

NN, McAdoo, Back from Russia Indorses Recognition Move, New York Post 1933 nr 290;

NN, Sculptress here, Brooklyn Daily Eagle (New York) 1932 nr 344;

NN, Sculptures by Maryla Lednicka, Brooklyn Daily Eagle (New York) 1934 nr 355;

O polskiej sztuce religijnej, red. J. Langman, Katowice 1932;

Or, Polska rzeźbiarka w Paryżu, Kurier Polski 1927 nr 195;

R. Ordyński, Polska rzeźbiarka w Mediolanie, Wiadomości Literackie 1926 nr 15;

The Oxford Dictionary of Christian Art and Architecture, red. T. Devonshire Jones, L. Murray, P. Murray, Oxford 2013;

Paryski Salon Jesienny, Świat $1921 \mathrm{nr} 51$;

Pierwsza Wystawa wspótczesnej polskiej sztuki kościelnej im. Piotra Skargi w Krakowie, Kraków 1911;

I. Piotrowska, Maryla Lednicka (1894-1947), Tygodnik Polski 1947 nr 14;

—, Maryla Lednicka. Great Polish Religious Sculptress (1895-1947), The Polish Review 1947 nr 11;

- The Art in Poland, New York 1947;

Z. Rotherowa, O Janinie Broniewskiej, Nowiny Literackie $1948 \mathrm{nr} 8$;

O. Rudenko, Wystawa Liturgiczna we Lwowie 1909 roku wobec wspótczesnej sztuki kościelnej, Teka Komisji Polsko-Ukraińskich Związków Kulturowych 2007;

C. Savart, Dwa wieki sporów wokót sztuki sakralnej, [w:] Historia chrześcijaństwa, red. A. Corbin, Kraków 2009;

Sculptors Guild presents: Sculpture of Freedom. Sept. 15 - Oct. 15. 1942, New York 1942;

W. Skrodzki, Polska sztuka religijna 1900-1945, Warszawa 1989;

T. B. Spitzer, Maryla Lednicka, Orzeł Biały 1947 nr 39; 
P. Szubert, Wśród figur, [w:] Figura w rzeźbie polskiej XIX i XX wieku, Warszawa 1999;

A. Wierzbicka, Artyści polscy w Paryżu. Antologia tekstów o polskiej kolonii artystycznej czynnej w Paryżu w latach 1900-1939, Warszawa 2008;

E. Wolicka, Sacrum i sztuka - punkty zapalne sporu, Znak $1991 \mathrm{nr} 12$;

E. Woroniecki, Artyści polscy w paryskim salonie [Jesiennym], Tygodnik Ilustrowany $1924 \mathrm{nr} 7$;

—, Polacy w Salonie Tuileryjskim, Tygodnik Ilustrowany 1924 nr 37;

—, Sztuka polska w salonach paryskich, Tygodnik Ilustrowany $1925 \mathrm{nr}$ 20;

Wystawa polskiej sztuki religijnej na Śląsku (katalog tymczasowy), Katowice 1931.

AMONG ANGELS AND SAINTS-THE EVOLUTION OF THE SCULPTURAL FORM IN THE WORKS OF MARYLA LEDNICKA-SZCZYTT

The article is an interpretation of the religious output by Maryla Lednicka-Szczytt. The unaffecting artist remained in the shadow of portrait sculpture and sacral sculpture, which played a significant role in Lednicka's artistic biography, providing an excuse for her personal artistic expression while at the same time enabling the utilisation of formal stylistics - with which the artist was the most familiar. Criticised by experts, not deprived of a particular naiveté, her works were not created for people, but for an unknown God and - most importantly-for herself, and this meant they did not have to meet the demands of critics. Lednicka's irreligious fervency demonstrated in sculpture compensates for the anatomical shortcomings and the formal imperfections of her works, making her an imperfect, yet painfully authentic artist.

KEYWORDS: asceticism; irreligion; artistic expression; religiousness; actualisation. 


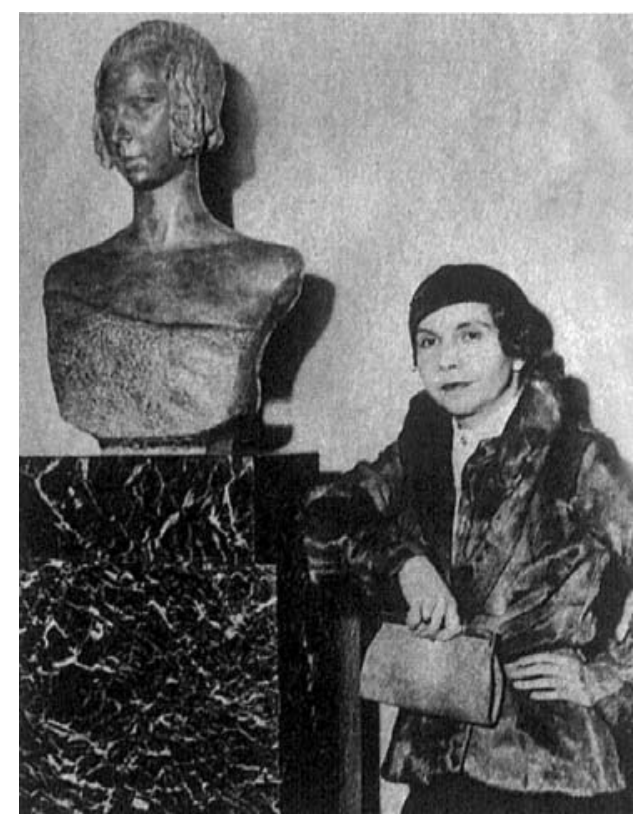

1. Maryla Lednicka-Szczytt przy Portrecie księżniczki Marii Piemonckiej swojego autorstwa

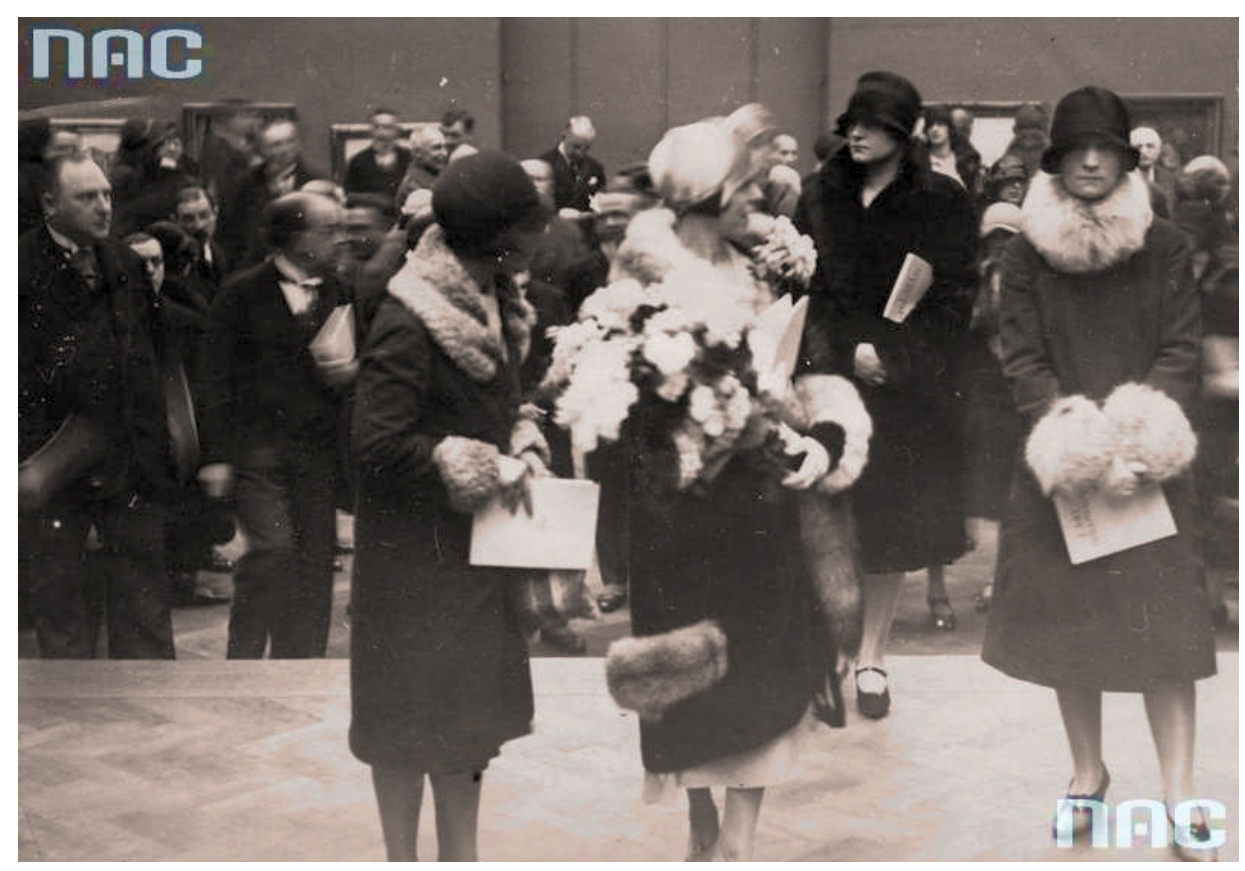

2. Maryla Lednicka-Szczytt (druga od lewej) na wystawie sztuki polskiej w Brukseli w 1928 roku 


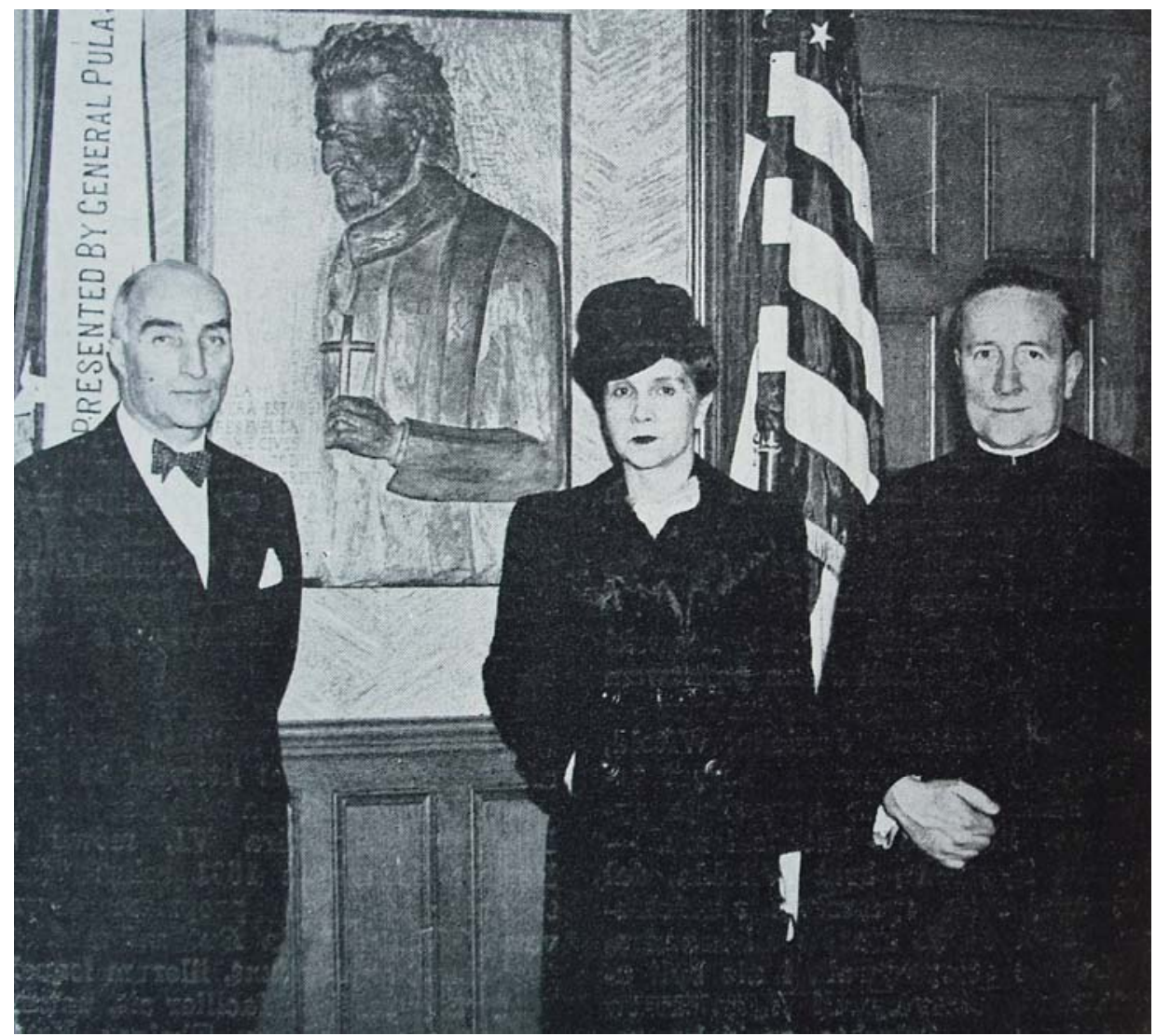

3. Maryla Lednicka-Szczytt na uroczystości odsłonięcia swojej płaskorzeźby przedstawiającej ks. Piotra Skargę na Uniwersytecie Fordham w Nowym Jorku 


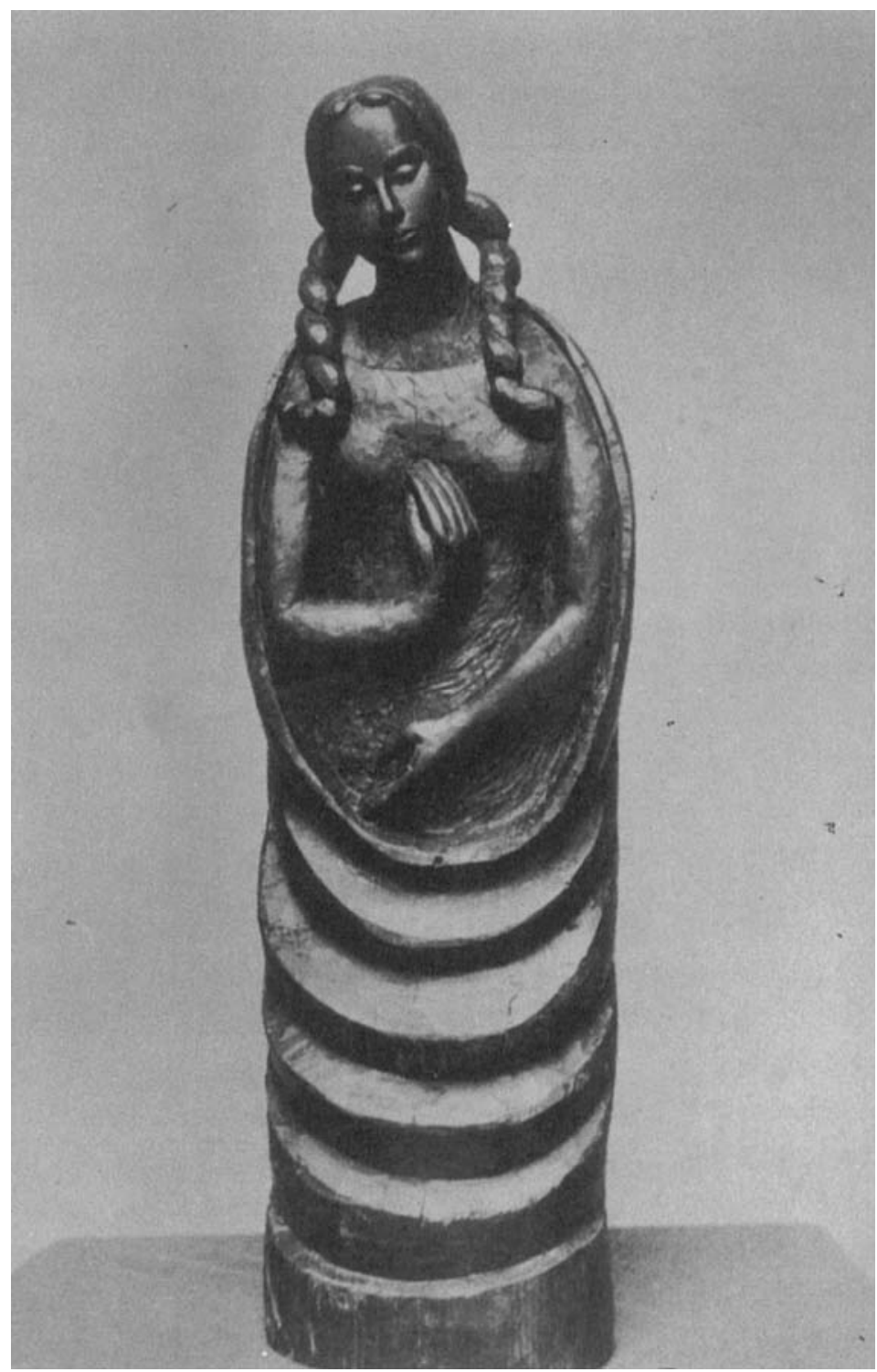

4. Madonna, drewno dębowe, ok. 1921 

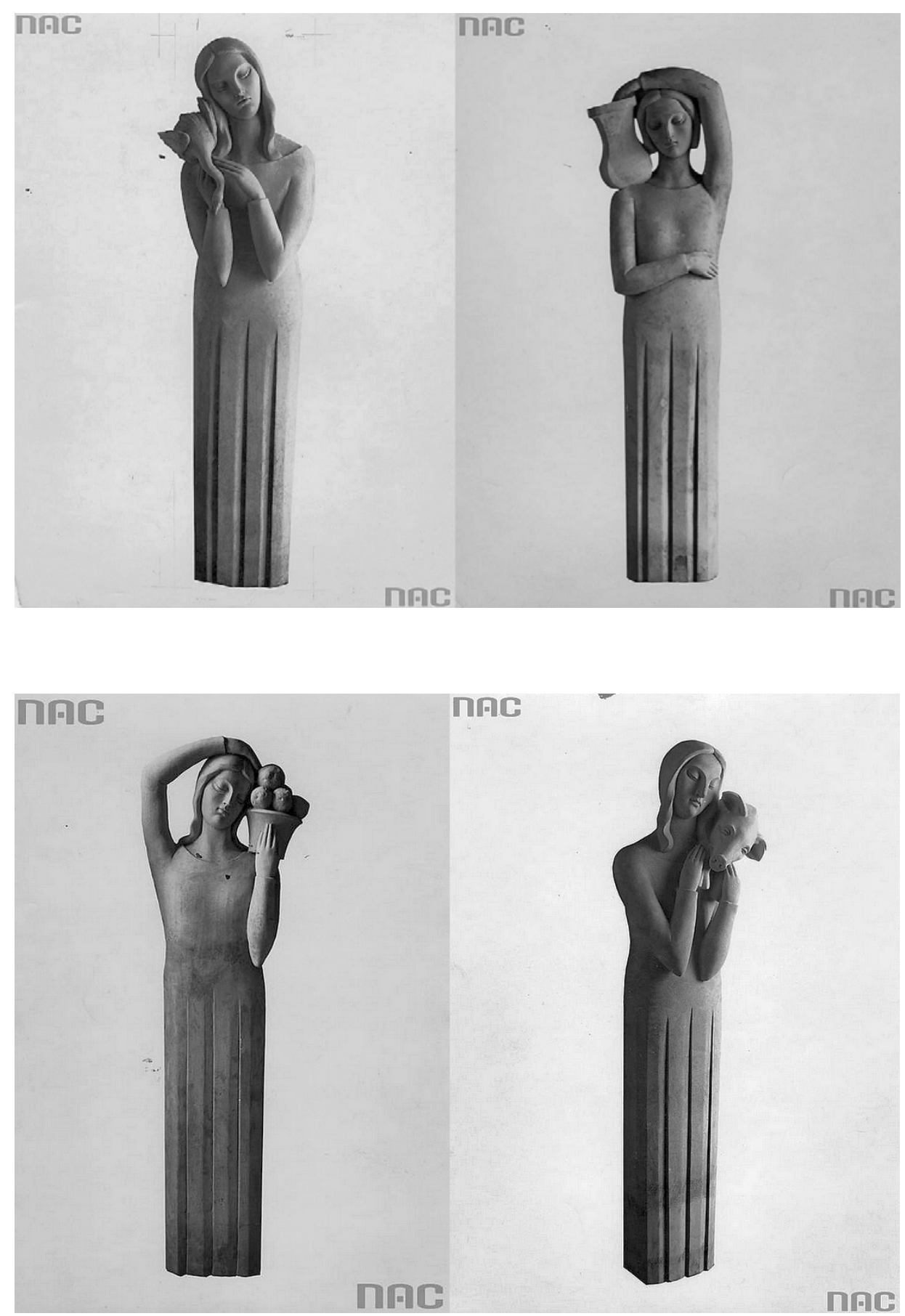

5. Kariatydy, kamień, 1928 


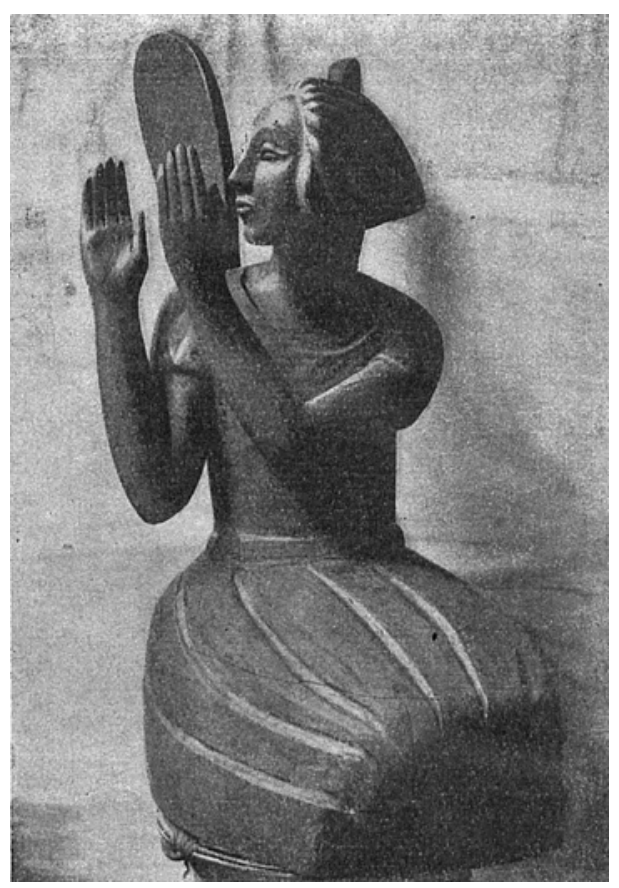

6. Czarny Aniot, drewno, ok. 1922

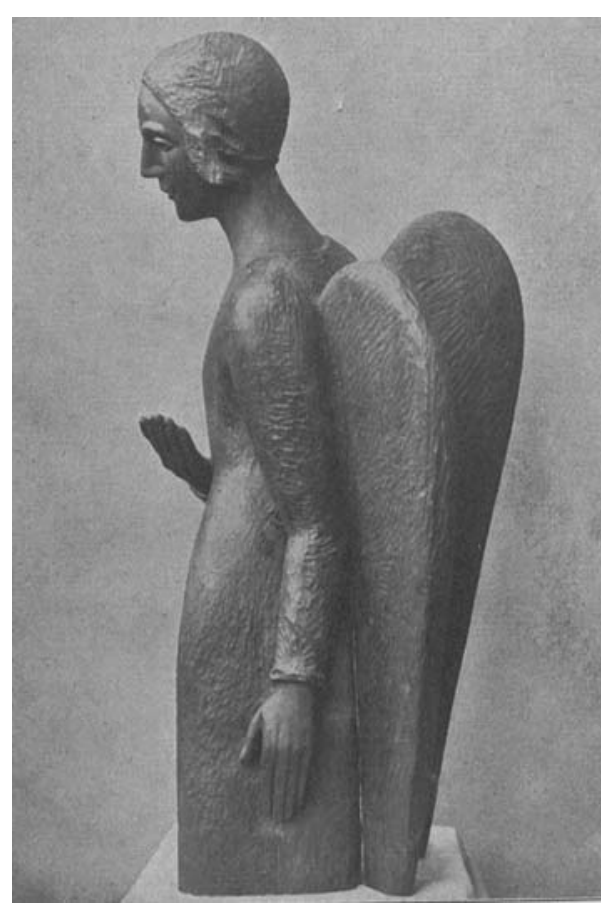

7. Aniot, braz (?), ok. 1928 


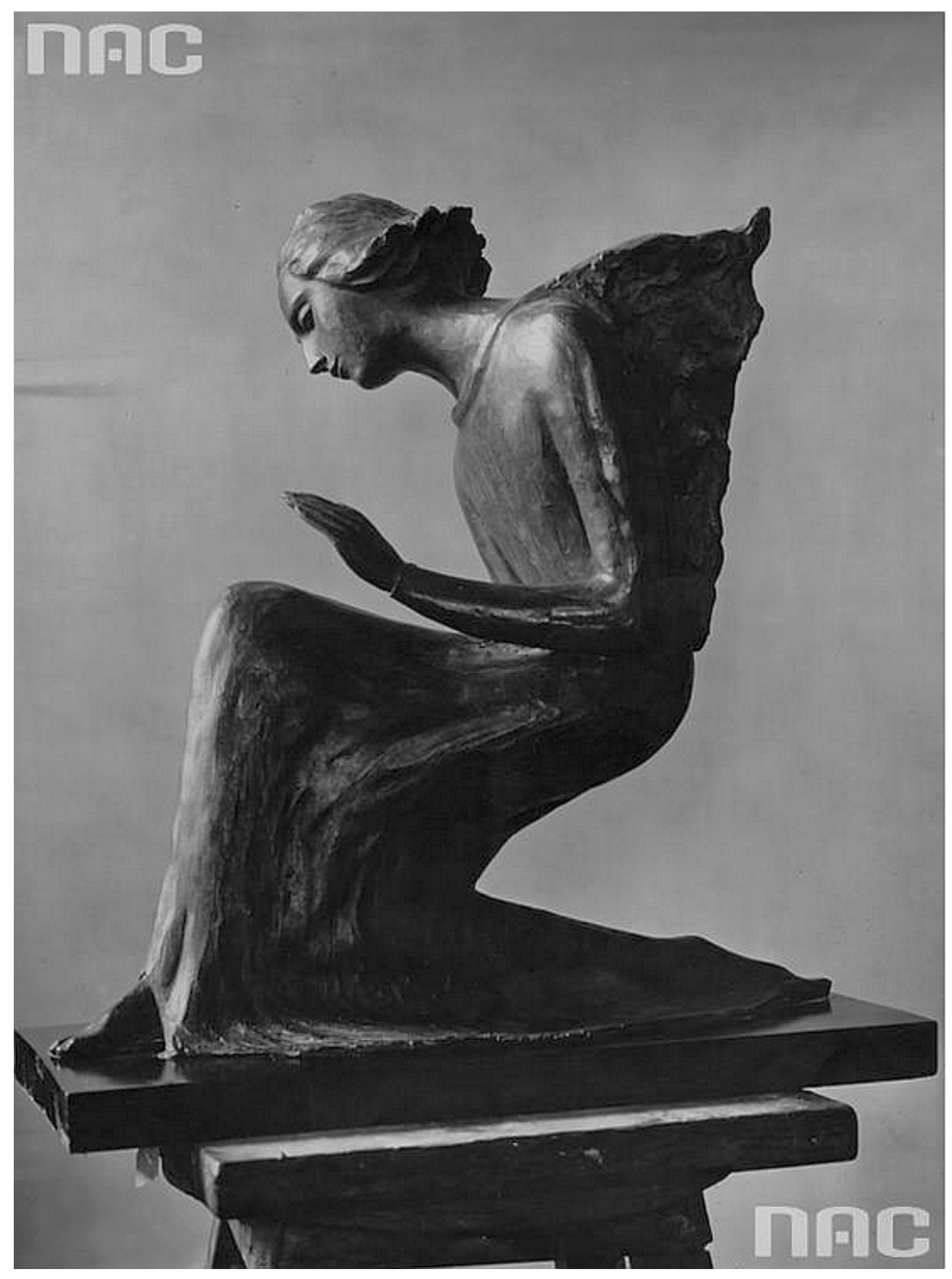

8. Klęczący Aniol, brąz, ok. 1931 


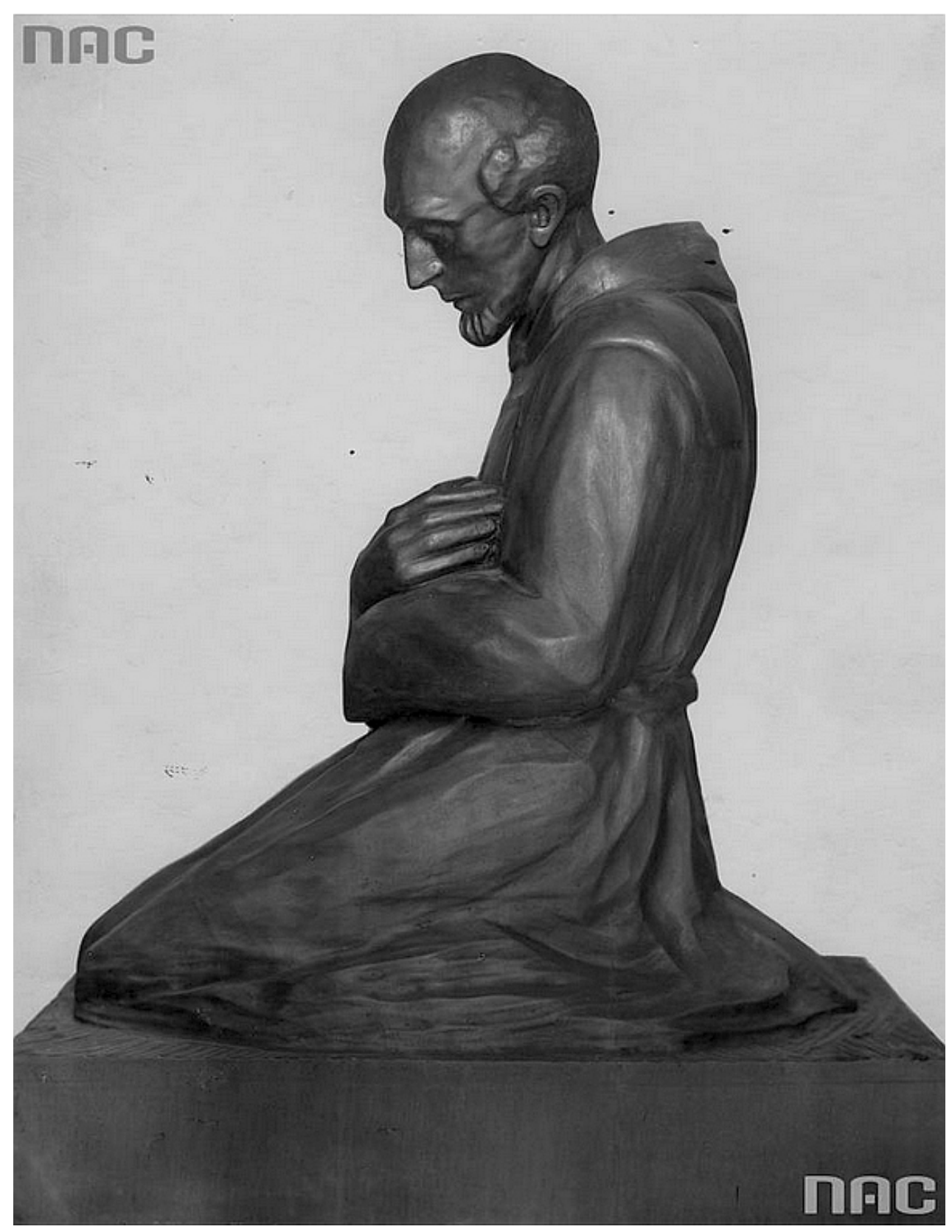

9. Święty Franciszek, brąz, ok. 1928 


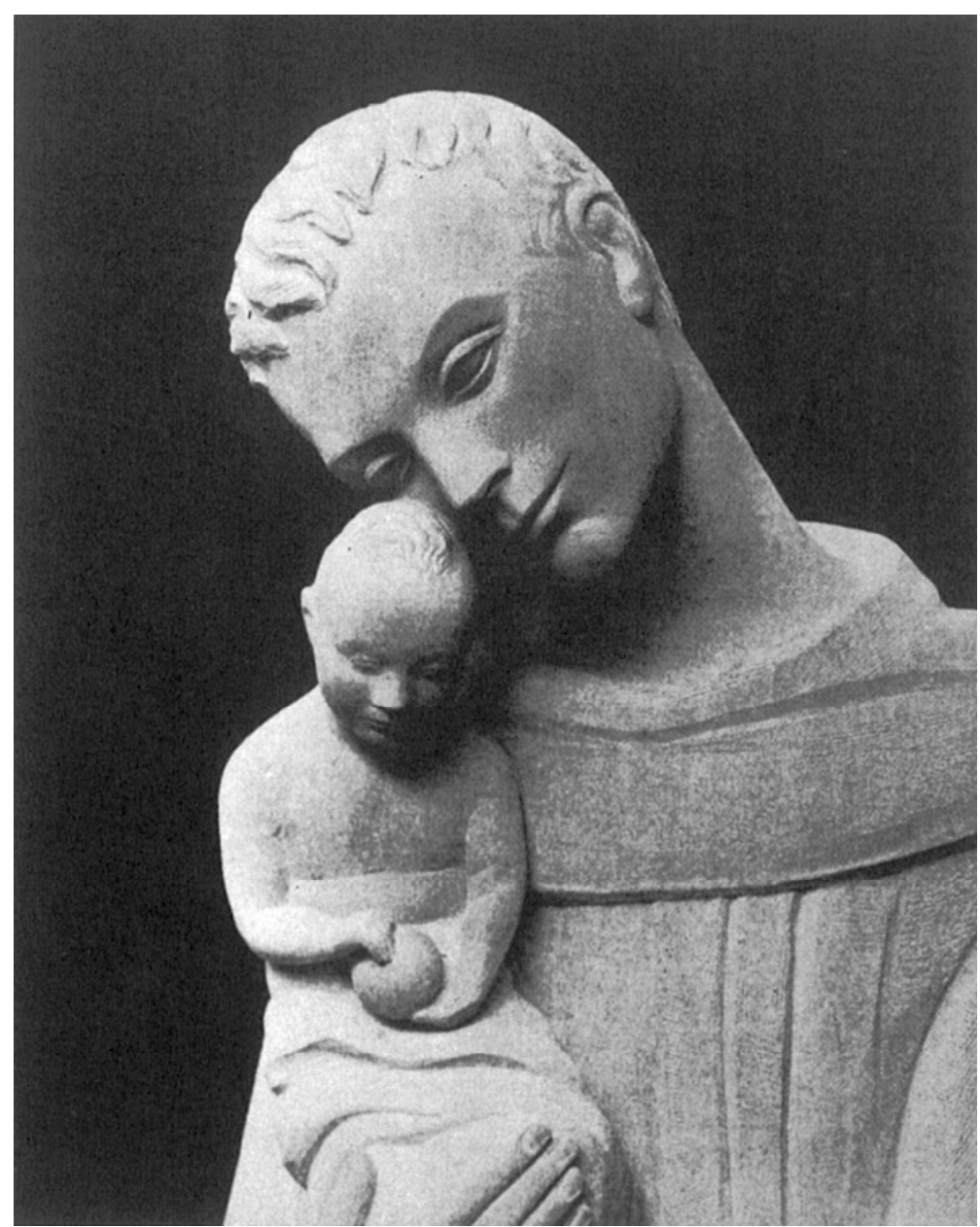

10. Święty Antoni z Padwy, wapień, po 1940 


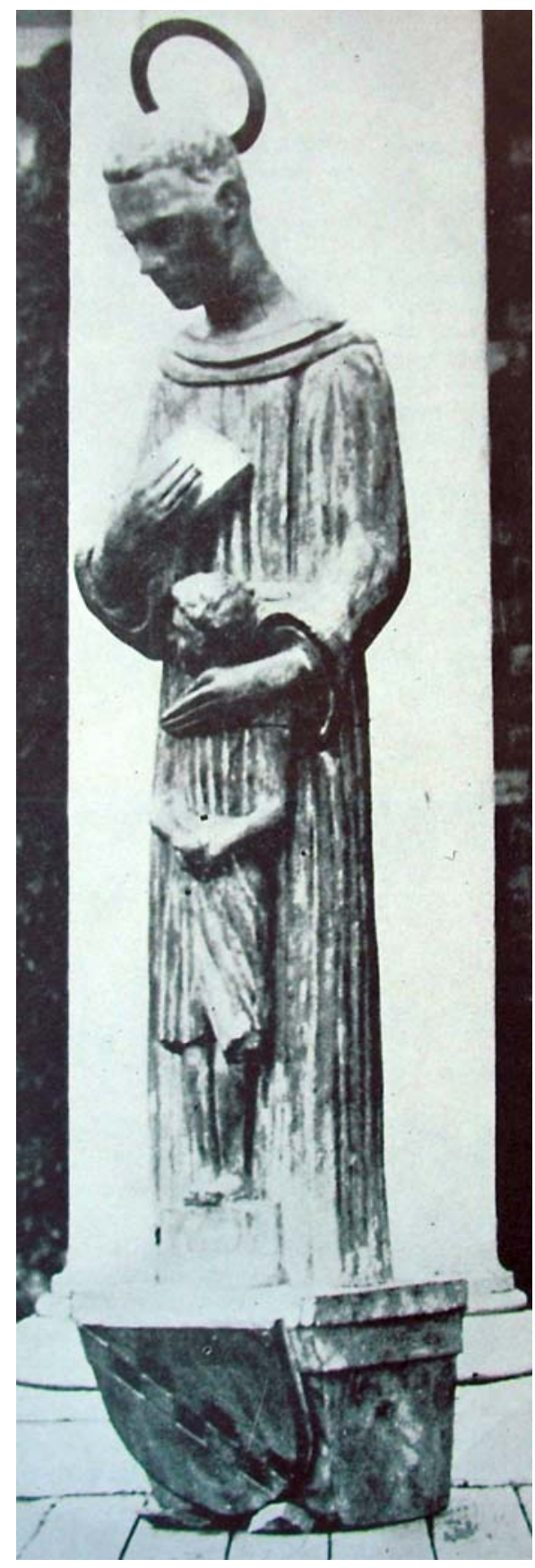

11. Święty Bernard, drewno, po 1942

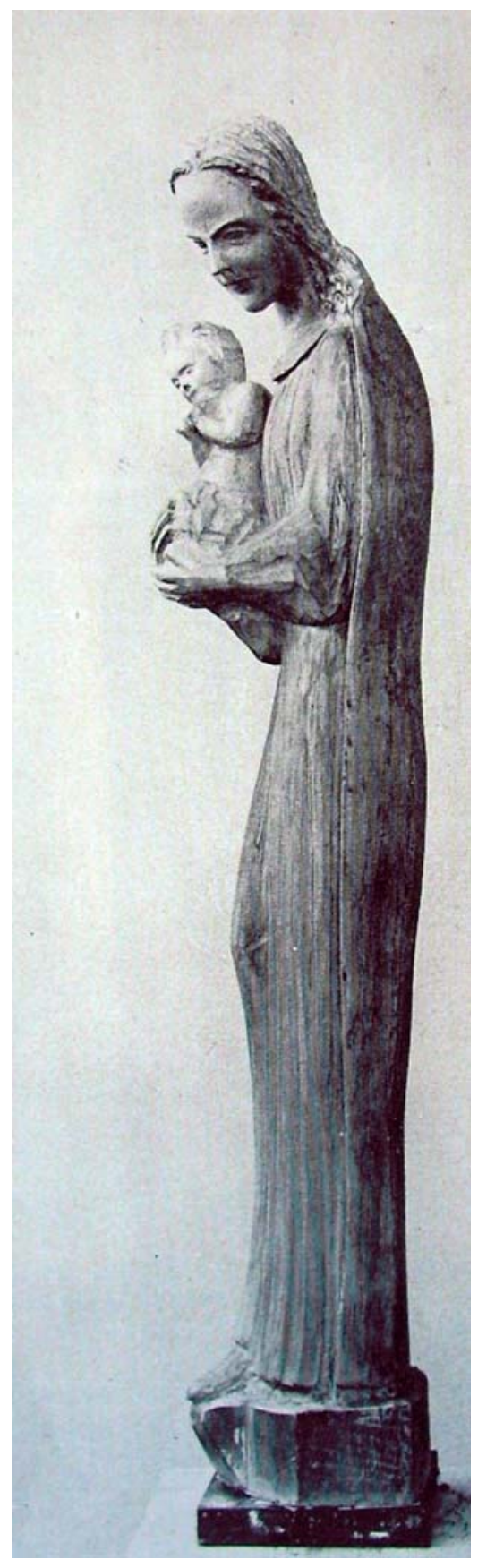

12. Madonna z Dzieciatkiem, drewno, po 1946 


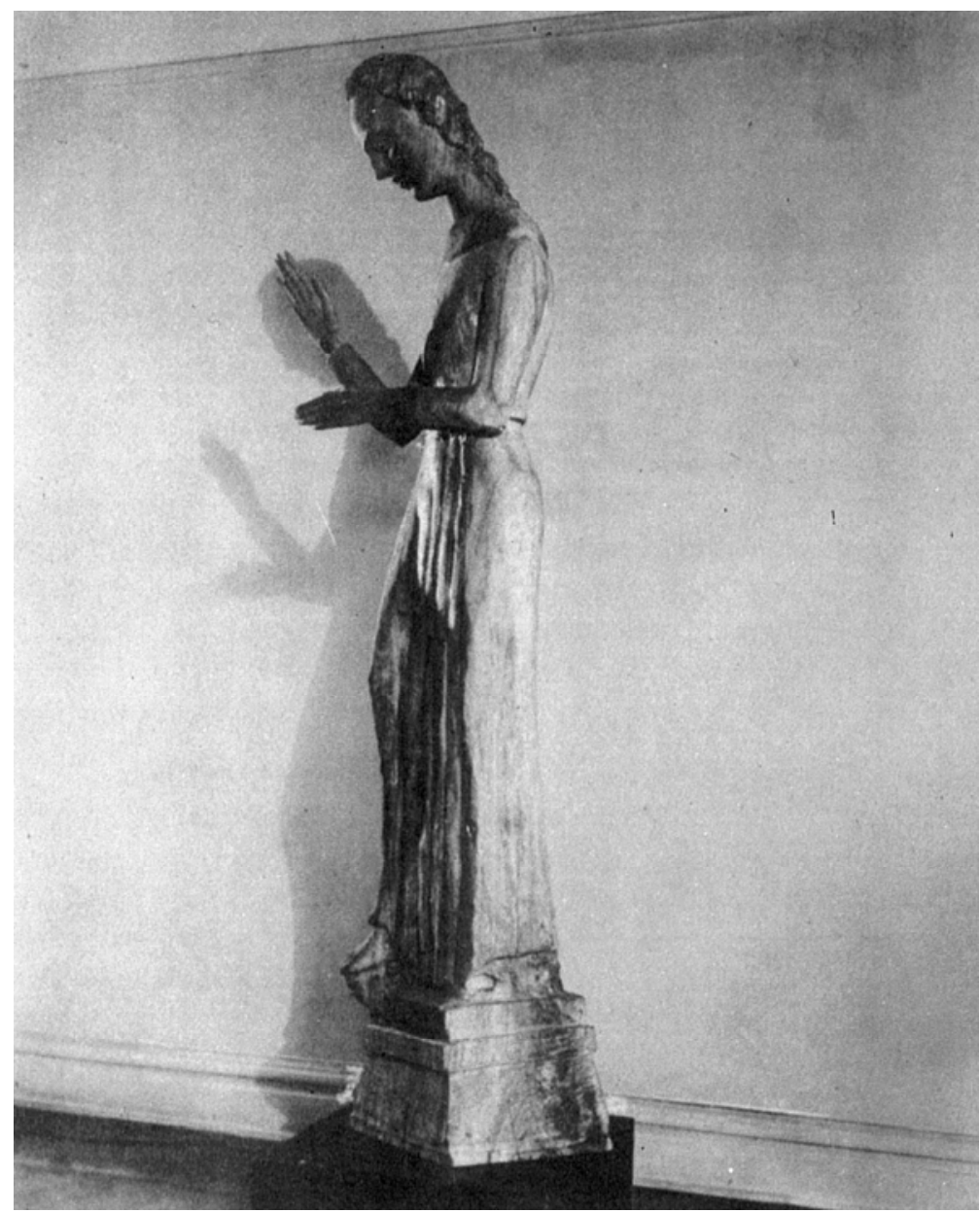

13. Duch Mistycyzmu, drewno, po 1940 